\title{
Sistem Informasi Pengolahan Data Pembelian Bahan Baku
}

\author{
Sri Muryani \\ Sekolah Tinggi Manajemen Informatika dan Komputer Nusa Mandiri \\ e-mail: sri.smy@nusamandiri.ac.id

\begin{tabular}{ccc}
\hline Diterima & Direvisi & Disetujui \\
$07-05-2020$ & $10-05-2020$ & $20-05-2020$ \\
\hline
\end{tabular}

\begin{abstract}
Abstrak - Bahan baku adalah faktor utama dalam pelaksanaan suatu proses produksi. Bahan baku adalah bahan yang digunakan dalam pembuatan produk dimana bahan sepenuhnya terlihat dalam produk jadi atau merupakan bagian terbesar dari bentuk barang. Ketersediaan bahan baku merupakan hal yang sangat penting bagi sebuah perusahaan. Pembelian bahan baku dalam suatu perusahaan membutuhkan investasi dana yang besar. Oleh karena itu, maka pengolahan data pembelian bahan baku menjadi kebutuhan tersendiri bagi sebuah perusahaan agar usahanya bisa berjalan dengan lancar. Sistem informasi pengolahan data pembelian bahan baku adalah sebuah sistem yang melakukan proses pengolahan data dan transaksi antara pihak yang membutuhkan atau mengolah aktiva produktif barang dagang atau barang jasa lainnya dengan pihak supplier. Pada penelitian ini berfokus pada pembelian bahan baku untuk perusahaan yang bergerak dalam bidang perdagangan busana muslim beserta aksesorisnya. Misalnya baju koko dewasa, baju koko anak, gamis dewasa, gamis anak, jilbab instans, jibab segi empat, bross dan lainnya. Penelitian ini bertujuan untuk membantu dalam dokumentasi kegiatan pembelian bahan baku sehingga pengolahan data pembelian bahan baku lebih efektif dan efisien.
\end{abstract}

Kata Kunci: sistem informasi, pengolahan data bahan baku.

\begin{abstract}
Raw material is the main factor in the implementation of a production process. Raw materials are materials used in the manufacture of products where the material is fully visible in the finished product or is a major part of the form of the goods. The availability of raw materials is very important for a company. Purchasing raw materials in a company requires a large investment of funds. Therefore, the processing of raw material purchase data is a separate requirement for a company so that its business can run smoothly. The raw material purchasing data processing information system is a system that carries out data processing and transactions between those who need or process productive assets of merchandise or other service goods with suppliers. In this study focuses on purchasing raw materials for companies engaged in the Muslim fashion trade and its accessories. For example, adult koko clothes, koko kids clothes, adult robe, kids robe, veil instances, rectangular hijab, bross and others. This study aims to assist in the documentation of raw material purchasing activities so that the processing of raw material purchase data is more effective and efficient.
\end{abstract}

Keywords: information systems, raw material data processing.

\section{PENDAHULUAN}

Menurut (Baroto, 2002) menyatakan bahwa bahan baku adalah barang-barang yang terwujud seperti tembakau, kertas, plastik ataupun bahanbahan lainnya yang diperoleh dari sumber-sumber alam atau dibeli dari pemasok, atau diolah sendiri oleh perusahaan untuk digunakan perusahaan dalam proses produksinya sendiri.

Menurut (Hanggana, 2006) bahan baku adalah sesuatu yang digunakan untuk membuat barang jadi, bahan pasti menempel menjadi satu dengan barang jadi.

Jenis-jenis bahan baku antara lain bahan baku langsung dan bahan baku tidak langsung. Bahan baku langsung adalah semua bahan baku yang meurpakan bagian dari produk jadi yang diproduksi. Biaya pembellian bahan baku terkait erat dan sebanding dengan jumlah produk jadi yang diproduksi.

Bahan baku tidak langsung adalah bahan baku yang berperan dalam proses produksi, tetapi tidak secara langsung terlihat pada produk akhir dari proses produksi. Contoh dari bahan baku adalah produk akhir pakaian, maka bahan baku langsung adalah kain. Sedangkan bahan baku tidak langsung adalah benang jahit.

Ketersediaan bahan baku dalam kuantitas dan ukuran yang dibutuhkan sangat mempengaruhi terhadap lancarnya suatu proses produksi. Pembelian bahan baku dalam suatu perusahaan membutuhkan investasi dana yang besar.

Oleh karena itu, maka pengolahan data pembelian bahan baku menjadi kebutuhan tersendiri 
bagi sebuah perusahaan agar usahanya bisa berjalan dengan lancar. Sistem informasi pengolahan data pembelian bahan baku adalah sebuah sistem yang melakukan proses pengolahan data dan transaksi antara pihak yang membutuhkan atau mengolah aktiva produktif barang dagang atau barang jasa lainnya dengan pihak supplier.

Menurut (Husda, 2016) sebuah sistem adalah sekumpulan benda yang meiliki hubungan diantara mereka.

Menurut (Pratama, 2014) system didefinisikan sebagai sekumpulan prosedur yang saling berkaitan dan saling terhubung untuk melakukan suatu tugas bersama-sama.

Menurut (Puspita, 2011) informasi adalah data yang diolah menjadi bentuk yang lebih berguna dan lebih berarti bagi yang menerimanya.

Menurut (Shalahuddin, 2015) "UML muncul karena adanya kebutuhan permodelan visual untuk memspesifikasikan, menggambarkan, membangun, dan dokumentasi dari sistem perangkat lunak".

Secara fisik, UML adalah sekumpulan spesifikasi yang dikeluarkan oleh OMG, UML terbaru adalah UML 2.3 yang terdiri dari 4 macam spesifikasi, yaitu Diagram Interchange Spesification, UML Infrastructure, UML Superstructure, dan Object Constraint Language (OCL).

Menurut (Pratama, 2014) "ERD (Entity Relationship Diagram) adalah diagram yang menggambarkan keterkaitan antartabel beserta dengan field-field di dalamnya pada suatu database sistem".

Pada penelitian ini berfokus pada pembelian bahan baku untuk perusahaan yang bergerak dalam bidang perdagangan busana muslim beserta aksesorisnya. Misalnya baju koko dewasa, baju koko anak, gamis dewasa, gamis anak, jilbab instans, jibab segi empat, bross dan lainnya. Penelitian ini bertujuan untuk membantu dalam dokumentasi kegiatan pembelian bahan baku sehingga pengolahan data pembelian bahan baku lebih efektif dan efisien

\section{METODE PENELITIAN}

Metode penelitian yang dilakukan dalam penelitian ini adalah :

a. Peninjauan lapangan (Observasi)

Metode ini dilakukan dengan cara meninjau secara langung kegiatan yang berhubungan dengan sistem pembelian bahan baku pada perusahaan.

b. Wawancara (Interview)

Pengumpulan data dilakukan dengan cara tanya jawab secara langsung dengan pihak-pihak yang memahami tentang pengolahan data bahan baku.

c. Kepustakaan (Library)
Peneliti melakukan pengumpulan data dengan membaca sumber-sumber tertulis yang terdapat dalam buku-buku referensi atau penelitian lain yang sesuai dengan tema penelitian ini.

Menurut Rosa dan Shalahuddin (2015:28), metode waterfall adalah "metode air terjun yang menyediakan pendekatan alur hidup perangkat lunak secara sekuensial atau terurut dimulai dari analisa, desain, pengkodean, pengujian, dan pendukung (support)",

Adapun tahapan dalam metode waterfall yang akan dijelaskan sebagai berikut:

1. Analisa

Analisa merupakan suatu kegiatan yang dimulai dari proses awal di dalam mempelajari sesuatu serta mengevaluasi suatu bentuk permasalahan yang ada.

2. Desain

Desain merupakan kegiatan dalam penggambaran, perencanaan, dan perancangan atau pengaturan dari beberapa elemen yang terpisah di dalam sistem menjadi kesatuan dan berfungsi dengan baik.

3. Pengkodean

Pengkodean merupakan upaya dalam pengimplementasian desain menjadi perangkat lunak.

4. Pengujian

Pengujian merupakan upaya dalam menelusuri lebih lanjut terhadap perangkat lunak yang telah dibuat untuk mendapatkan informasi mengenai kualitas perangkat lunak yang sedang diuji.

5. Pendukung

Pendukung merupakan kegiatan yang dilakukan dalam perawatan dan pengubahan atau pengembangan dari perangkat lunak yang telah dibuat dan tidak terdeteksi saat tahapan pengujian.

\section{HASIL DAN PEMBAHASAN}

Analisa Kebutuhan

A. Halaman Bagian Pembelian

A. 1. Bagian Pembelian mengakses Login

A. 2. Bagian Pembelian mengelola Data Barang

A. 3. Bagian Pembelian mengelola Data Supplier

A. 4. Bagian Pembelian mengelola transaksi Pemesanan

A. 5. Bagian Pembelian mengelola transaksi Pembayaran

A. 6. Bagian Pembelian mengelola Laporan

B. Pimpinan

B. 1. Bagian Keuangan mengakses Login

B. 2. Bagian Keuangan mengakses menu laporan 


\section{Use Case Diagram}

Use case diagram dibuat untuk mengetahui fungsi apa saja yang ada didalam sebuah sistem informasi, dan siapa saja yang berhak menggunakan fungsi tersebut. Didalam sistem informasi pengolahan data pembelian bahan baku, ada dua buah use case yang ditampilkan. Yaitu use case login dan use case menu utama.

\section{Use Case Diagram Login}

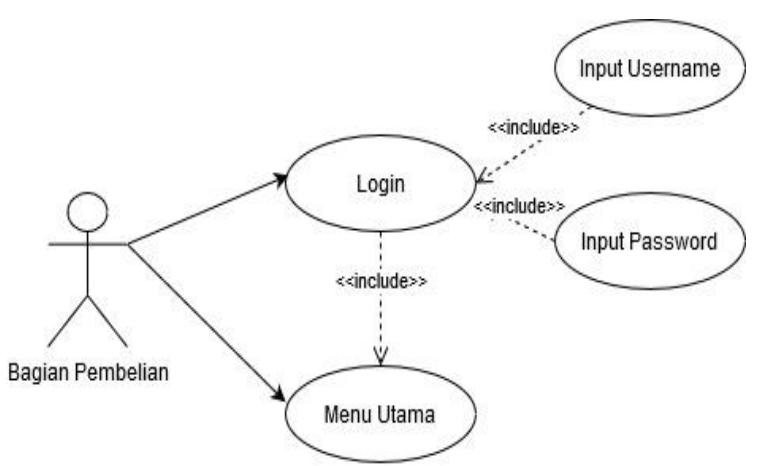

Sumber: Hasil Penelitian (2020)

Gambar 1. Use Case Diagram Login

Tabel 1. Deskripsi Use Case Login Pembelian Bahan Baku

\begin{tabular}{|c|c|}
\hline \multicolumn{2}{|c|}{ Use Case Narative Login } \\
\hline Tujuan & $\begin{array}{l}\text { Melakukan login dan } \\
\text { masuk ke dalam sistem } \\
\text { pembelian bahan baku }\end{array}$ \\
\hline Deskripsi & $\begin{array}{l}\text { Sistem ini memungkinkan } \\
\text { aktor untuk mengakses } \\
\text { sistem pembelian bahan } \\
\text { baku }\end{array}$ \\
\hline \multicolumn{2}{|c|}{ Skenario Utama } \\
\hline Aktor & Bagian Pembelian \\
\hline Kondisi Awal & $\begin{array}{l}\text { Aktor membuka sistem } \\
\text { pembelian bahan baku }\end{array}$ \\
\hline Aksi Aktor & Reaksi Sistem \\
\hline $\begin{array}{ll}\text { 1. } & \text { Aktor } \\
\text { memilih } \\
\text { tombol Login } \\
\text { 2. Aktor } \\
\text { memilih } \\
\text { tombo Keluar }\end{array}$ & $\begin{array}{l}\text { 1. Sistem akan } \\
\text { menampilkan textbox } \\
\text { untuk mengisi } \\
\text { username dan } \\
\text { password. } \\
\text { 2. Sistem keluar dari } \\
\text { form login. }\end{array}$ \\
\hline Kondisi Akhir & $\begin{array}{l}\text { Jika perintah sesuai maka } \\
\text { sistem akan masuk } \\
\text { kedalam sistem pembelian } \\
\text { bahan baku dan melakukan } \\
\text { aktifitas didalam sistem. }\end{array}$ \\
\hline
\end{tabular}

\section{Use Case Diagram Menu Utama}

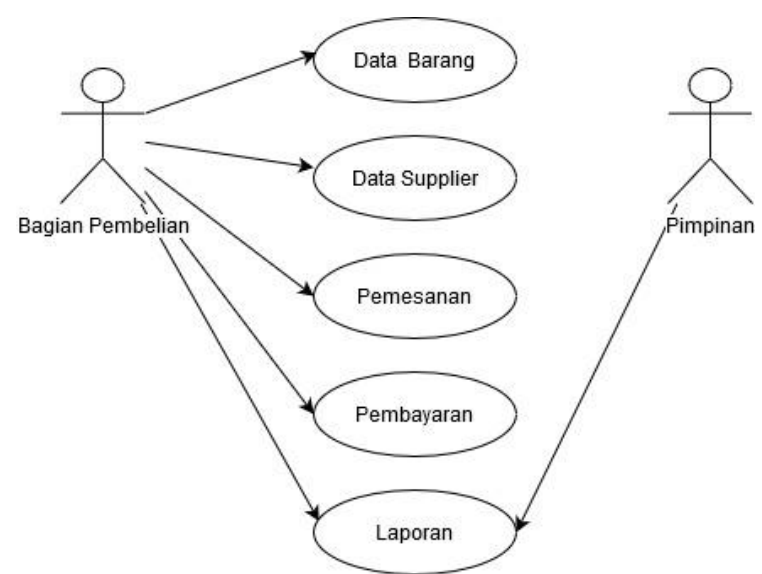

Sumber: Hasil Penelitian (2020)

Gambar 2. Use Case Diagram Menu Utama

Pembelian Bahan Baku

Tabel 2. Deskripsi Use Case Menu Utama Pembelian Bahan Baku

\begin{tabular}{|c|c|}
\hline \multicolumn{2}{|c|}{ Use Case Narative Menu Utama } \\
\hline Tujuan & $\begin{array}{l}\text { Bagian Pembelian dapat } \\
\text { mengakses menu yang ada } \\
\text { pada menu utama yaitu } \\
\text { Data Barang, Data Supplier, } \\
\text { Pemesanan, Pembayaran } \\
\text { dan Laporan. }\end{array}$ \\
\hline Deskripsi & $\begin{array}{l}\text { Sistem ini memungkinkan } \\
\text { aktor untuk mengelola } \\
\text { seluruh menu yang ada } \\
\text { didalam menu utama. }\end{array}$ \\
\hline \multicolumn{2}{|c|}{ Skenario Utama } \\
\hline Aktor & Bagian Pembelian \\
\hline Kondisi Awal & $\begin{array}{l}\text { Aktor membuka sistem } \\
\text { pembelian bahan baku }\end{array}$ \\
\hline Aksi Aktor & Reaksi Sistem \\
\hline $\begin{array}{l}\text { 1. Aktor } \\
\text { memilih Data } \\
\text { Barang }\end{array}$ & $\begin{array}{l}\text { 1. Sistem akan } \\
\text { menampilkan data } \\
\text { barang }\end{array}$ \\
\hline $\begin{array}{l}\text { 2. Aktor } \\
\text { memilih Data } \\
\text { Supplier }\end{array}$ & $\begin{array}{l}\text { 2. Sistem akan } \\
\text { menampilkan data } \\
\text { supplier }\end{array}$ \\
\hline $\begin{array}{l}\text { 3. Aktor } \\
\text { memilih } \\
\text { Pemesanan }\end{array}$ & $\begin{array}{l}\text { 3. Sistem akan } \\
\text { menampilkan data } \\
\text { pemesanan barang }\end{array}$ \\
\hline $\begin{array}{l}\text { 4. Aktor } \\
\text { memilih } \\
\text { Pembayaran }\end{array}$ & $\begin{array}{l}\text { 4. Sistem akan } \\
\text { menampilkan data } \\
\text { pembayaran. }\end{array}$ \\
\hline $\begin{array}{l}\text { 5. Aktor } \\
\text { memilih } \\
\text { Laporam }\end{array}$ & $\begin{array}{l}\text { 5. Sistem akan } \\
\text { menampilkan hasil dari } \\
\text { laporan }\end{array}$ \\
\hline Kondisi Akhir & $\begin{array}{l}\text { Jika perintah sesuai maka } \\
\text { sistem akan menampilkan } \\
\text { seluruh menu dalam menu } \\
\text { utama }\end{array}$ \\
\hline
\end{tabular}




\section{Activity Diagram}

Activity diagram adalah diagram yang menggambarkan aliran kerja atau aktifitas dari sebuah sistem. Activity diagram yang ditampilkan pada penelitian ini adalah diagram login dan diagram data barang.

\section{Activity Diagram Login}

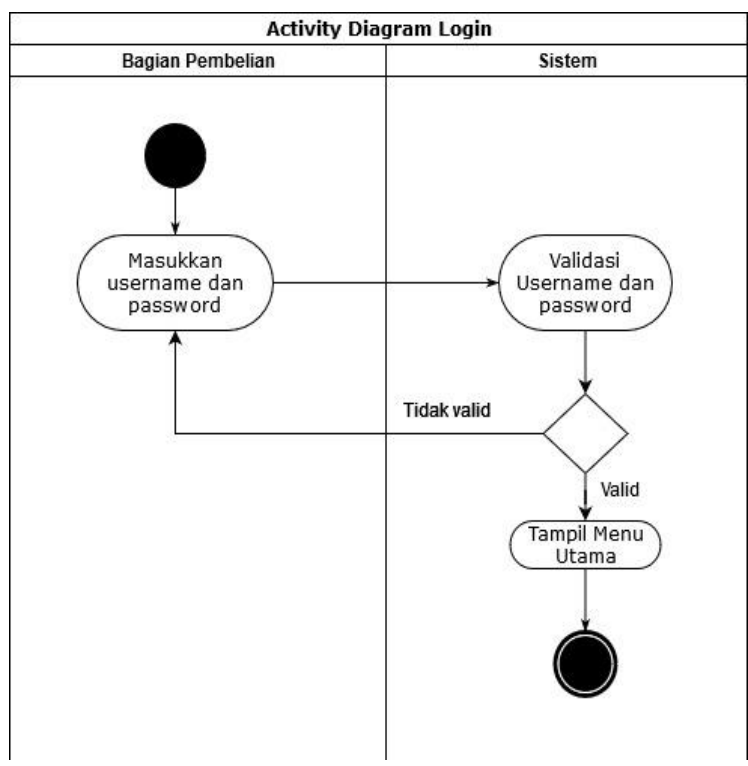

Sumber: Hasil Penelitian (2020)

Gambar 3. Activity Diagram Login

Dalam activity diagram login bisa dilihat bahwa bagian pembelian akan memasukkan username dan password untuk masuk ke menu utama. Selanjutnya username dan password akan divalidasi oleh sistem pembelian bahan baku. Jika username dan password yang diinput salah maka akan kembali ke proses input username dan password. Jika input username dan password benar, maka akan masuk kedalam menu utama.

\section{Activity Diagram Data Barang}

Dalam activity diagram barang bisa dilihat bagian pembelian mengakses form barang. Hal pertama yang dilakukan klik menu form barang, maka sistem akan menampilkan form barang. Klik tambah jika ingin menambahkan data.

Input kode barang dilakukan, lalu sistem akan melakukan pengecekan data apakah kode barang tersebut sudah ada atau belum. Jika kode barang sudah ada maka sistem akan menampilkan keseluruhan data barang. Jika kode barang belum ada, maka bagian pembelian bisa melanjutkan untuk input data barang yang lainnya. Misalnya nama barang, jumlah, harga.

Setelah data selesai di input semua, maka bagian pembelian bisa memilih simpan untuk melakukan penyimpanan data. Atau memilih batal jika data batal disimpan.

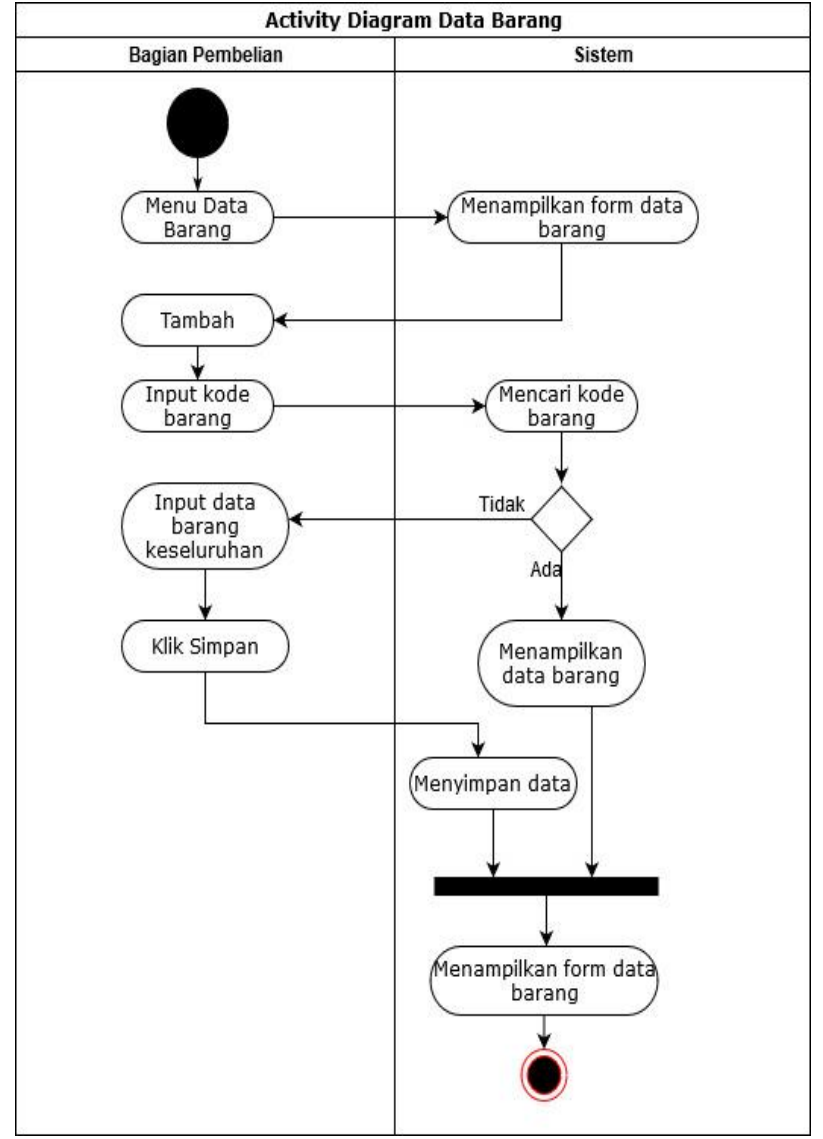

Sumber: Hasil Penelitian (2020)

Gambar 4. Activity Diagram Data Barang

\section{Desain}

Desain merupakan perencanaan dalam pembuatan sebuah objek sistem komponen dan struktur. Desain merupakan seni terapan dan rekayasa yang berintegrasi dengan teknologi.

Proses desain pada umumnya memperhitungkan aspek fungsi, estetika dan berbagai macam aspek lainnya dengan sumber data yang didapatkan dari riset, pemikiran, maupun dari desain yang sudah ada sebelumnya.

\section{Class Diagram}

Class Diagram adalah sebuah spesifikasi yang jika diinstansiasi akan menghasilkan sebuah objek dan merupakan inti dari pengembangan dan desain berorientasi objek.

Didalam class diagram dapat dilihat rancangan database yang nantinya dipakai. Dapat terlihat ada class user, barang, supplier, pemesanan, detail-pesan, pembayaran. 


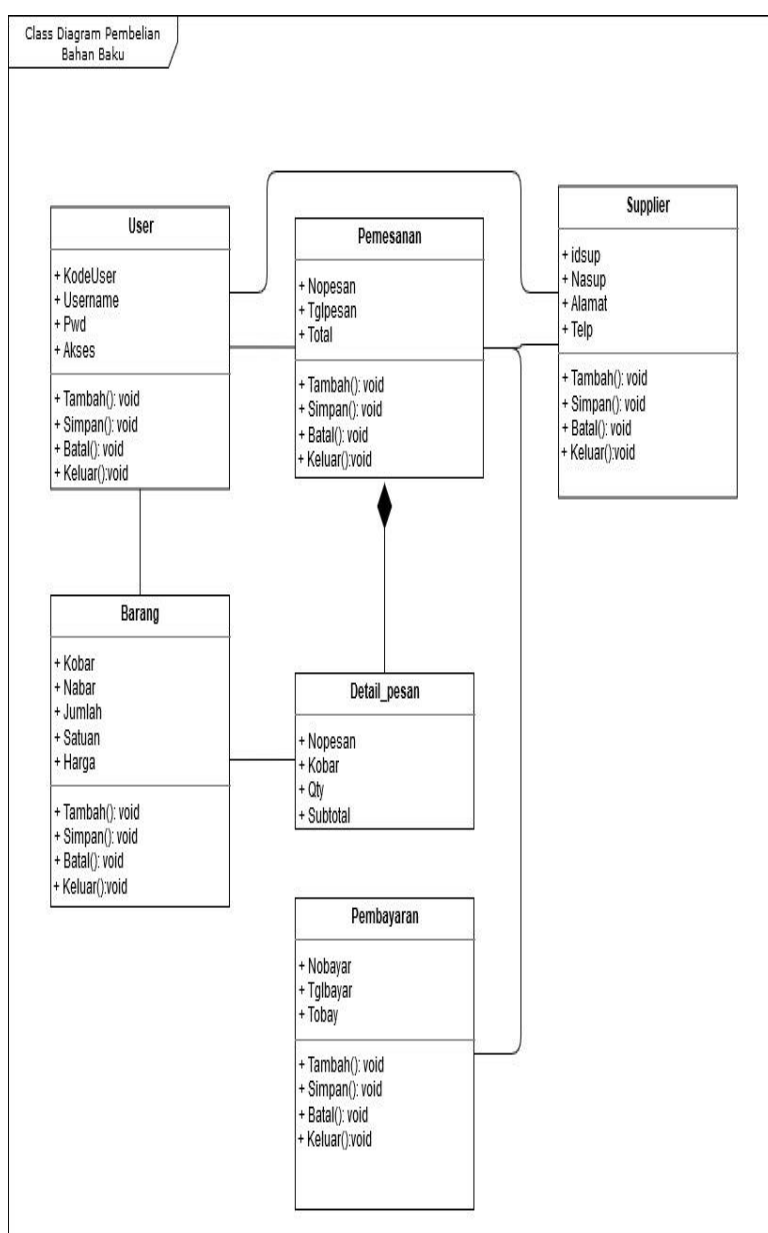

Sumber: Hasil Penelitian (2020)

Gambar 5. Class Diagram Pembelian Bahan Baku

\section{User Interface}

User interface yang sering disingkat UI, merupakan bentuk tampilan grafis yang berhubungan langsung dengan pengguna. User interface berguna untuk menghubungkan antara pengguna dengan sistem operasi, sehingga komputer bisa digunakan.

\section{Login}

Berikut ini merupakan tampilan user interface login. Bisa di akses disaat user akan melakukan login kedalam sistem pembelian bahan baku.

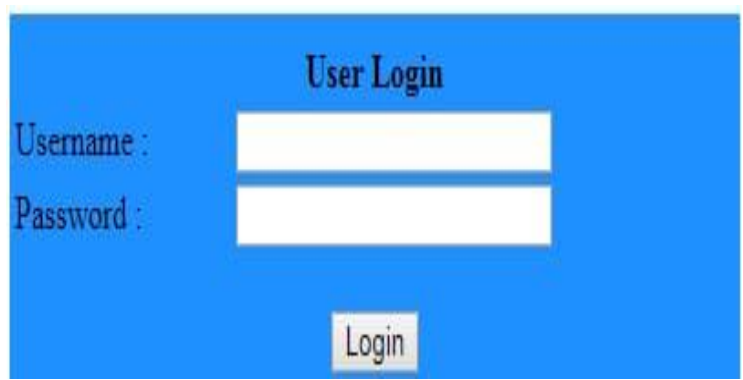

Sumber: Hasil Penelitian (2020)

Gambar 6. User Interface Login

\section{Menu Utama}

Berikut ini merupakan tampilan user interface menu utama. Dapat dilihat pilihan menu barang, supplier, pemesanan, pembayaran dan laporan. Menu ini bisa diakses setelah user melakukan login. Pada penelitian ini user adalah bagian pembelian.

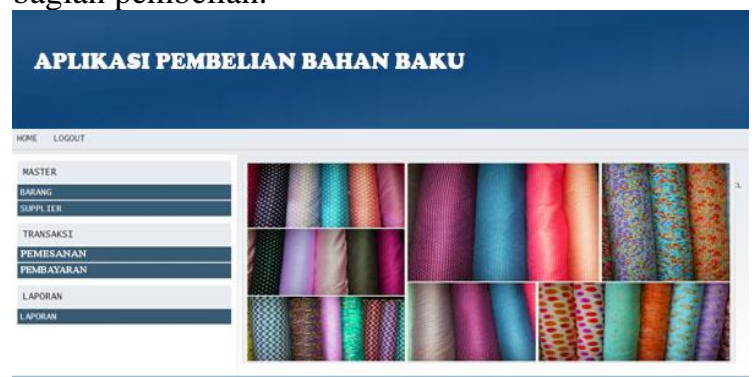

Sumber: Hasil Penelitian (2020)

Gambar 7. User Interface Menu Utama

\section{Data Barang}

Berikut ini merupakan tampilan user interface menu utama. Dapat dilihat pilihan menu barang, supplier, pemesanan, pembayaran dan laporan. Menu ini bisa diakses setelah user melakukan login. Pada penelitian ini user adalah bagian pembelian.

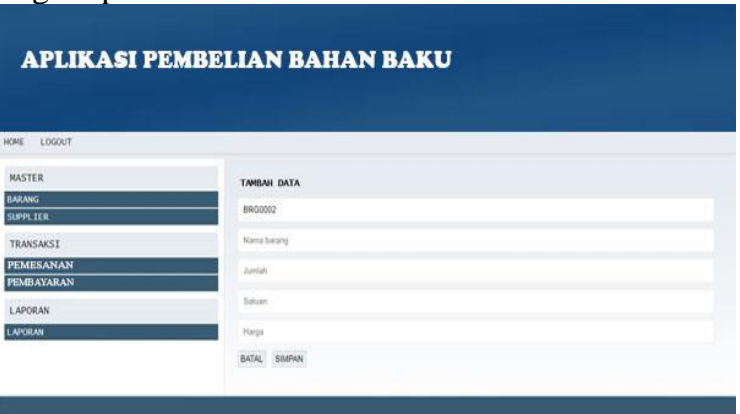

Sumber: Hasil Penelitian (2020)

Gambar 8. User Interface Data Barang

\section{Pemesanan}

Berikut ini merupakan tampilan user interface menu utama. Dapat dilihat pilihan menu barang, supplier, pemesanan, pembayaran dan laporan. Menu ini bisa diakses setelah user melakukan login. Pada penelitian ini user adalah bagian pembelian.

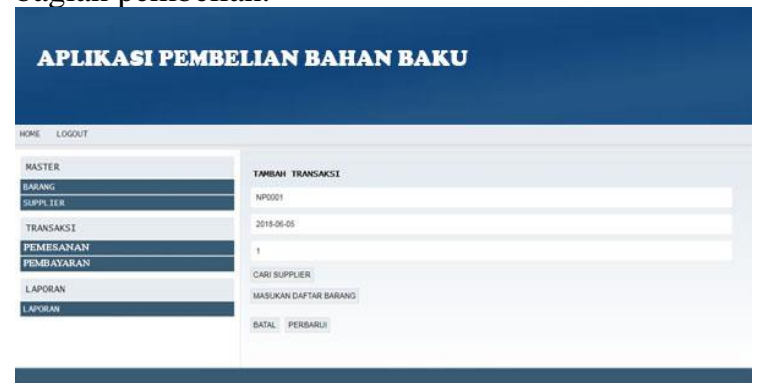

Sumber: Hasil Penelitian (2020)

Gambar 9. User Interface Pemesanan 


\section{KESIMPULAN}

Sistem informasi pengolahan data pembelian bahan baku dalam penelitian ini mencakup input data barang, supplier, pemesanan, pembayaran hingga cetak laporan. Berdsasarkan uraian yang sudah ada didalam hasil dan pembahasan, maka akan disampaikan kesimpulan.

Kesimpulan dari hasil penelitian ini adalah menggunakan aplikasi yang digunakan untuk pengolahan data pembelian bahan baku, maka dapat mempermudah dalam penginputan transaksi yang dilakukan oleh perusahaan.

Dalam hal menyimpan data dapat menjadi aman dan tersusun secara sistematis hingga nantinya lebih mudah untuk mengarsipkan data atau file dan juga menemukan datanya. Hasil akhir aplikasi ini dapat menghasilkan laporan yang disajikan dengan tepat dan memberikan informasi kepada pimpinan.

\section{REFERENSI}

Baroto, T. (2002). Perencanaan dan Pengendalian Produksi. Jakarta: Ghalia Indonesia.

H., J. (2005). Analisa dan Desain Sistem Informasi: Pendekatan Terstruktur Teori dan Praktik Aplikasi Bisnis. Edisi 3. Yogyakarta: Andi Offset.
Hanggana, S. (2006). Prinsip Dasar Akuntansi Biaya. Surakarta: Mediatama.

Hartono, J. (2001). Analisis dan Desain Sistem Informassi. Edisi Kedua. Yogyakarta: Andi Offset.

Husda, N. E. (2016). Pengantar Teknologi Informasi. Jakarta: Baduose Media.

Kendall, K. d. (2013). Analisis dan Perancangan Sistem. Klaten: PT. Intan Sejati.

Krismiaji. (2015). Sistem Informasi Akuntansi. Yogyakarta: UPP STIM YKPN.

Ladjamudin, A. (2013). Analisis dan Desain Sistem Informasi. Yogyakarta: Graha Ilmu.

Mardi. (2014). Sistem Informasi Akuntasi. Bogor: Ghalia Indonesia.

Pratama, A. E. (2014). Sistem Informasi dan Implementasinya. Bandung: Informatika Bandung.

Puspita, L. S. (2011). Sistem Informasi Akuntansi. Yogyakarta: Graha Ilmu.

R.A. Sukamto, M. S. (2014). Rekayasa Perangkat Lunak. Bandung.

Shalahuddin, R. d. (2015). Rekayasa Perangkat Lunak Terstruktur dan Berorientasi Objek. Bandung: Informatika Bandung.

Yakub. (2012). Pengantar Sistem Informasi. Yogyakarta: Graha Ilmu. 